\title{
Influence of Mole Drains and N-Fertilizer Sources on Rhizosphere activity and Rice Yield in Heavy Clay Salt Affected Soil at North Nile Delta
}

\author{
M. M. Shabana ${ }^{1}$, A. S. Kheir ${ }^{1}$, R. M. Khalifa ${ }^{* 2}$, and A. Sh. Antar ${ }^{1}$ \\ ${ }^{1}$ Soils, Water and Environment Res. Inst., Agric. Res. Center, Egypt \\ ${ }^{2}$ Soils Department, Faculty of Agriculture Damietta University, Damietta, Egypt.
}

\begin{abstract}
$\mathbf{T}$ HE INTEGRATION mole drains as a low-cost drainage system with nitrogen fertilizers particularly ammonia gas to improve salt affected soils have a little attention. A field experiment was conducted at North Nile Delta , during the two summer seasons (2016 and 2017), to determine the impact of mole drains (mole drains in one direction and mole drains in two directions with open drainage) and nitrogen sources (urea, ammonium sulphate and ammonia gas injection) with gypsum addition (3ton fed.-1 for all plots) on improving some soil physio-chemical properties, rice productivity and N-uptake by plant as well as productivity of irrigation water (PIW), nitrogen application efficiency (NAE) and economic returns from rice production and water unit.

Results indicated that the application of mole drain along with open drainage seems to be favorably effective in reducing salinity and sodicity of the soil particularly in case of using two directions. The combination system of mole and open drainage resulted in a reduction of soil bulk density and soil penetration resistance, while increased the basic infiltration rate. Moreover, it had with ammonia gas injection a superiority in the increase of rice yield (ton/ fed.), N-uptake and nitrogen use efficiency compared with other treatments, accordingly this combination produced the important findings of such approach in improving salt affected soils and rice production. From the economic view, the optimum values of NAE, PIW, economic efficiency and net return from water unit for rice yield were achieved using mole application with open drainage and ammonia gas injection
\end{abstract}

Keywords: Ammonia gas injection, Clay salt affected soil, Economic return, Irrigation water, Mole drain, Rice, Productivity..

\section{Introduction}

The North-Eastern parts of Egypt could be considered problematic vertisol areas, suffering from low productivity due to existence of salinity, sodicity and low efficient drainage (Seleiman and Kheir, 2018). The sources of salinity in Egyptian delta are not limited to sea water intrusion, waterlogging and irrigation water quality (Negm, 2017). Recently, soil degradation and nutrient have become serious threat to agricultural productivity, especially in clayey soil. One way to increase production is proper soil management such as drainage and improving the efficiency of application nitrogen fertilizer. One of the most significant factors that can overcome of such problems is drainage (FAO., 2016 and Anon., 2001). Mole drainage is a construction of underground channel with neither digging a trench nor using tubes, to move the excess water consequently the soluble salts from soil surface (Kolekar et al., 2014). Mole drain, therefore, can be considered as intermediate system between surface drainage and subsurface drainage which considered an expensive system particularly in developing countries (Bennett et al.,2005). Moling is a potential way in clay soils to avoid water logging and salinity (David, 2002). Moreover, several researchers have indicated the positive findings might be achieved after applying adequate mole drain system especially at heavy clay soils (Moukhtar et al., 2002 and Antar et 
al., 2016). The important role of mole drainage in heavy clay soils is mainly attributed to the physical action of mole on hardpan shattering and thus increasing water and solutes movement in soil profile (Antar et al., 2012 \& 2016 and Aiad et al., 2012). Consequently, mole drains would decrease soil bulk density, penetration resistance and increasing total (El-Henawy et al., 2016 and Bennett et al., 2005).

In Egypt, the consumption of mineral fertilizers, specially nitrogen fertilizers have tripled during the last years (FAO., 2005), with the increase of global fertilizers prices. The amount of $\mathrm{N}$-fertilizers to be applied depend on the crop requirements and nitrogen stored in the soil at beginning of the crop cycle. Anhydrous ammonia is one of the most efficient and widely used as source of nitrogen for plant growth (Antar and Awad, 2014). The advantages of ammonia application is relatively easy implementation and ready availability have led to its increased use as a fertilizer. (AbdEl-Kader, 2002) reported that when the anhydrous ammonia injected before sowing, produced the optimum yield and minerals uptake than other nitrogen sources. (Atia et al., 2007) compared ammonia gas with urea, they found that first progressed than urea. Ammonia gas could be considered a good and low cost source of nitrogen fertilizer compared with any other $\mathrm{N}$ source and achieved the maximum economic return, (Zalat et al., 2011). Nevertheless, the behavior of ammonia gas in salt affected soils under various drainage systems has less attention so far.

Rice (Oryza sativa) is the second important crop for grains production in Egypt. Rice crop is moderately salt tolerant, and it is recommended to be common at Nile delta soils to keep a permanent head of water above ground water to limits sea water intrusion (Arafat et al., 2010). Based on the abovementioned information the current study aims toevaluating the integration effects of mole drains with combined nitrogen fertilizer sources and Their effects on soil physical and chemical properties, rice productivity, N-uptake by plant, productivity of irrigation water, nitrogen application efficiency and economic returns. The novelty of this investigation is using cheaper and more efficient sources of nitrogen fertilizers (i.e., ammonia gas) as integration with also cheaper drainage systems (i.e. open drainage and mole drainage) under salt affected soils.

\section{Materials and Methods}

A field experiment was conducted at North Nile Delta (Al-Hamul District, Kafer El-Sheikh
Governorate, Egypt), during the two summer seasons (2016 and 2017), to determine the impact of mole drains (open drainage without mole drains, mole drains in one direction with open drainage and mole drains in two directions with open drainage) and nitrogen fertilizer sources (urea, ammonium sulphate and ammonia gasinjection)on improving some soil physicochemical properties and rice productivity as well as $\mathrm{N}$-uptake by plant, productivity of irrigation water and economic returns. The experiment is located at $31^{\circ} 24^{\prime} 41.50^{\prime \prime}$ Latitude and $31^{\circ} 04^{\prime}$ $31.47^{\underline{ }}$ Longitude. Some soil properties before conducting the experiments are presented in Table 1. Means of some meteorological data at Kafr El-Sheikh areaduring the two growing seasons of 2016 and 2017 are shown in Table 2. The experiment was arranged in split plot design, with three replications, where the main plots were assigned to mole drains and the sub plot were nitrogen sources as follows:

Main plots: mole drains treatments

1. Open drainage without mole drains

2. Mole drains in one direction with open drainage.

3. Mole drains in two directions (network) with open drainage.

Sub plots: nitrogen sources

1. Urea $(46.5 \% \mathrm{~N})$.

2. Ammonium sulphate $(20.6 \% \mathrm{~N})$.

3. Ammonia gasinjection $(82 \% \mathrm{~N})$.

Nitrogen fertilizer (Urea, ammonium sulphateand ammonia gas) were applied at rate of $75 \mathrm{~kg} \mathrm{~N}$ fed. ${ }^{-1}$ (as recommended). Mole drains was established at $2 \mathrm{~m}$ distances between the lines for one and two direction and at $60 \mathrm{~cm}$ depth in onedirection and the first direction in the case of two directions. While, the second direction in the case of two directions mole depth was $45 \mathrm{~cm}$ perpendicular to first direction."Mole drains are unlined channels formed in a clay subsoil with a ripper blade with a cylindrical foot, often with an expander which helps compact the channel wall." Open drains at $30 \mathrm{~m}$ spacing and $80 \mathrm{~cm}$ depth was used to collect the drainage water brought by mole drain channels. The salinity of irrigation water ranges between $0.9-1.18 \mathrm{dSm}^{-1}$ with an average of $1.04 \mathrm{dSm}^{-1}$.In the summer season (2016) rice (Oryza sativa) Giza 178 cultivar was transplanted in $7^{\text {th }}$ June, 2016 and $11^{\text {th }}$ June, 2017. All plots received $50 \mathrm{~kg}^{-1} \mathrm{fed}^{-1} \mathrm{Ca}$-superphosphate $(15.5 \%$ $\mathrm{P}_{2} \mathrm{O}_{5}$ ) during tillage operation and nitrogen (as urea $46.5 \%$ and ammonium sulphate 20.6\%) 
was applied in two doses after 15 and 35 days from transplanting. Nitrogen (as ammonia gas) was injected at 10 to $15 \mathrm{~cm}$ soil depth, before cultivation. After five days from ammonia gas injection, rice was transplanted.All plots received $3 \mathrm{Mgfed}^{-1}$ of gypsum before cultivation. The different agricultural practices were done as recommended. Gypsum requirements were determined according to the methods described by U.S., salinity laboratory staff (FAO and IIASA, 2000), so $3.0 \mathrm{Mgfed}^{-1},(\mathrm{Mg}=$ metric tons $)$ are sufficient to reduce the initial ESP from 16.24 to $12 \%$ for 30 -cm soil matrix as follows:

$$
\mathrm{GR}=\left(\mathrm{ESP}_{\mathrm{i}}-\mathrm{ESP}_{\mathrm{F}}\right) / 100 \times \mathrm{CEC} \times 1.72
$$

Where GR: gypsum requirement $\left(\mathrm{Mgfed}^{-1}\right), \mathrm{ESP}_{\mathrm{i}}$ : initial soil ESP, ESP: the required soil ESP and CEC: cation exchange capacity $\left(\mathrm{cmol}_{\mathrm{c}} \mathrm{kg}^{-1}\right)$.

Soil samples $(0-15,15-30$ and 30-60 cm depth) were collected before conducting the experiment and after harvesting the first and second seasons from treatments instillation and monitored for some physical and chemical analysis. Salinity was determined in saturated soil paste extract according to Page et al. (1982). Exchangeable sodium was determined using ammonium chloride and measured by using flame photometer according to Page et al. (1982). Infiltration rate was determined using double cylinder infiltrometer as described by Garcia (1978). Soil bulk density and total porosity of the different layers of soil profile were measured after first and second seasons using the core sampling technique as described by Campbell (1994) for all treatments. Soil penetration resistance (SPR) was determined by hand penetrometer apparatus (Herrick and Jones 2002) (Read by Newten $/ \mathrm{cm}^{2}$ ) and, convert the Newten into Mega Pascal (MPa) values $\left(100 \mathrm{Newten} / \mathrm{cm}^{2}=1\right.$ Mega Pascal $)$.

Rice was harvested on the $11^{\text {th }}$ of September, 2016 and $14^{\text {th }}$ of September, 2017. Rice yields was measured for different treatments, grains and straw samples were taken and dried at $70^{\circ} \mathrm{C}$, grounded with a mill and its total $\mathrm{N}$ content was determined using Kjeldahl digestion (Cottenie et al.,1982). N-uptake (kgfed.-1) was calculated by multiplying dry yield $\left(\mathrm{kgfed} .^{-1}\right)$ by $\mathrm{N} \%$ for both grains and straw. Available $\mathrm{N}$ content of soil was determined using Kjeldahl digestion (Cottenie et al., 1982).
Nitrogen application efficiency (NAE\%) was calculated as follows

$$
N A E=\frac{\mathrm{N} \text {-uptake }+N-\text { residual }}{\mathrm{N} \text {-native }+\mathrm{N} \text {-applied }} \times 10 \mathrm{o}
$$

Where:

N-Native: The base content of nitrogen in soil before cultivation

N- Residual Nitrogen content in soil after harvesting

N-Applied: Artificial application of nitrogen

Applied irrigation water

Irrigation intervals for the rice each 4 days and theamount of irrigation water was measured by using a rectangular sharp crested weir. The discharge was calculated using the following equation as described by (Masoud, 1969).

$$
\mathrm{Q}=\mathrm{CL}(\mathrm{H})^{\wedge} 1.5
$$

Where: $\mathrm{Q}=$ Discharge $\left(\mathrm{m}^{3} \mathrm{~s}^{-1}\right)$

$\mathrm{L}=$ Length of the crest (m).

$\mathrm{H}=$ Head above the weir $(\mathrm{m})$.

$\mathrm{C}=$ Empirical coefficient determined from discharge measurement.

Productivity of irrigation water (PIW, $\mathrm{kgm}^{-3}$ ) was calculated according to Ali et al. (2007) as follows:

$$
\mathrm{PIW}=\mathrm{Gy} / \mathrm{WA}, \text { where }
$$

$\mathrm{Gy}=$ Grain and straw yields, $\mathrm{kg} \mathrm{fed}^{-1}, \mathrm{WA}=$ Water applied, $\mathrm{m}^{3}$ fed ${ }^{-1}$

\section{Economic evaluation}

Cash inflows and out flows for various treatments (at prices of the local market) were calculated, and some economic indicators were estimated according to the equations outlined by FAO, (2000). Such as:

- Net return: it can be calculated by deducting the total cost from the total return, $\left(\right.$ LEfed $\left.^{-1}\right)$

- Economic efficiency: it can be calculated by dividing the total seasonal net return on total seasonal cost

- Net return from water unit: it can be calculated by dividing seasonal net return (LE $\left.\mathrm{fed}^{-1}\right)$ on seasonal water applied $\left(\mathrm{m}^{3} \mathrm{fed}^{-1}\right)$

\section{Statistical analysis}

Data for grains and straw yields of rice were recorded and were subjected to statistical analysis by ANOVA technique according to Snedecor and Cochran (1980). Treatments were compared by Duncan's multiple range test (Duncan, 1955) . 

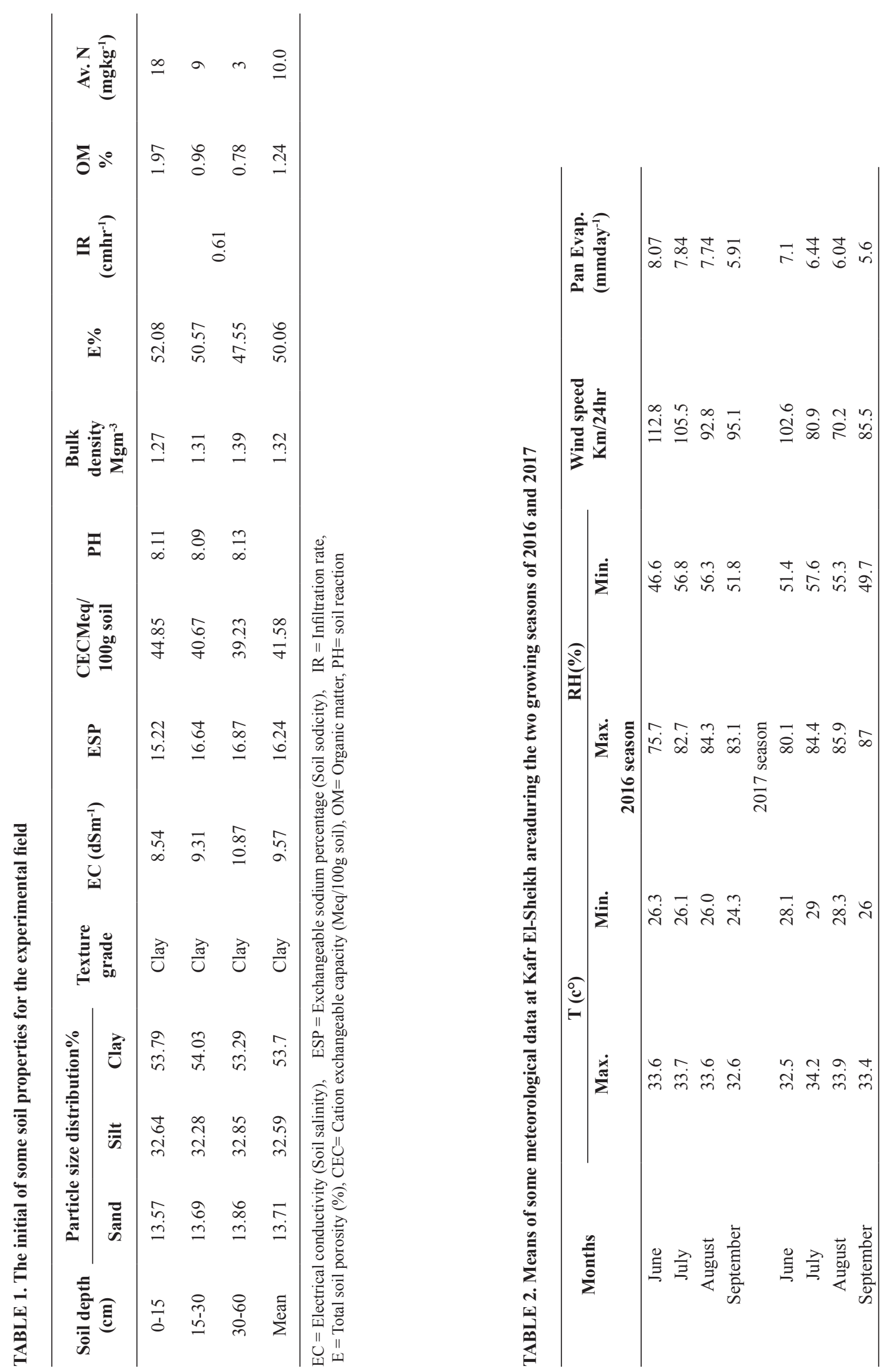

J. Sus. Agri. Sci. 44, No. 2 (2018) 


\section{Results and Discussion}

Salinity and alkalinity of soil

Mole with open drainage applications are shown in Table 3 and showed a favorable superiority in decreasing soil salinity (ECe) and sodicity (ESP). Salinity and sodicity of the soil, are relatively high with open drainage without mole drains application. Soil samples after the treatments application showed a significant decrease in ECe and ESP values, where the average values of ECe and ESP, respectively were $8.92 \mathrm{dSm}^{-1}$ and 15.73 in the first season, and were $8.86 \mathrm{dSm}^{-1}$ and 15.50 in the second season with open drainage without mole, resulted in decreasing ECe values by $6.79,7.40 \%$, and $3.17,4.56 \%$ decrease in ESP values after $1^{\text {st }}$ and $2^{\text {nd }}$ season, respectively than that in the initial experimental field. Molingapplications are more pronounced on reduction of salinity and sodicity especially, after the second season from mole application with open drainage. Salinity reduced with mole application than without mole by 16.31 and $27.96 \%$ after first season and about 24.64 and $36.96 \%$ after second season for one and two directions, respectively. Also, sodicity reduced as a result of mole application than without mole by 6.47 and $9.59 \%$ after first season and about 9.55 and $11.78 \%$ following second season for one and two directions, respectively.
The effect of mole application with open drainage on decreasing both salinity and sodicity are shown in Table 3 . The highest decreasing rate was noticed following mole application, this is mainly due to forming many lines with wide cracks through soil profile subjected to mole application. Such cracks are responsible for breaking the soil matrix leading to facilitating water and solute movement. Consequently, the effect of mole drains on soil salinity and sodicity recession, which occurred only through mole depth. The decrease of ESP as affected by construction of treatments can be attributed to increase the leaching of $\mathrm{Na}^{+}$ions compared with calcium and magnesium salts and consequently decreasing of SAR (Abdel-Mawgoud et al., 2003). In this concern, (Ali and Kahlown, 2001) mentioned that reclamation of saline - sodic and sodic soils, however, cannot be achieved by simple leaching. Reclamation of these soils is difficult, time consuming and more expensive than that of saline soils due to replacement of exchangeable sodium with calcium. Hence, it requires the addition of chemical amendments such as gypsum along with leaching. Similar results were observed by ElHenawy et al. (2016). Results in Table 3 showed that nitrogen fertilizer sources (urea, ammonium sulphate and ammonia gas) had no significant effect on salinity and sodicity of the soil for both seasons.

TABLE 3. Salinity and sodicity of the soil as influenced by different studied treatments

\begin{tabular}{|c|c|c|c|c|c|c|}
\hline \multirow{2}{*}{\multicolumn{2}{|c|}{ Treatments }} & \multirow{2}{*}{ Soil depth (cm) } & \multicolumn{2}{|c|}{ After first season } & \multicolumn{2}{|c|}{ After second season } \\
\hline & & & EC dS m ${ }^{-1}$ & ESP & $E C d^{2} ~ m^{-1}$ & ESP \\
\hline \multirow{9}{*}{$\begin{array}{l}\text { Open drainage } \\
\text { without mole } \\
\text { drains }\end{array}$} & \multirow{3}{*}{ Urea } & $0-15$ & 7.85 & 15.36 & 7.49 & 15.14 \\
\hline & & $15-30$ & 8.48 & 15.65 & 8.54 & 15.25 \\
\hline & & $30-60$ & 10.75 & 16.34 & 10.84 & 16.21 \\
\hline & \multirow{3}{*}{$\begin{array}{l}\text { Ammonium } \\
\text { sulphate }\end{array}$} & $0-15$ & 7.33 & 15.24 & 7.21 & 15.11 \\
\hline & & $15-30$ & 8.52 & 15.68 & 8.24 & 15.14 \\
\hline & & $30-60$ & 10.76 & 16.29 & 10.88 & 16.21 \\
\hline & \multirow{3}{*}{$\begin{array}{l}\text { Ammonia gas } \\
\text { injection }\end{array}$} & $0-15$ & 7.33 & 15.34 & 7.03 & 15.01 \\
\hline & & $15-30$ & 8.54 & 15.66 & 8.57 & 15.05 \\
\hline & & $30-60$ & 10.72 & 15.97 & 10.96 & 16.37 \\
\hline \multirow{9}{*}{$\begin{array}{l}\text { Mole drains in } \\
\text { one direction } \\
\text { with open } \\
\text { drainage }\end{array}$} & \multirow{3}{*}{ Urea } & $0-15$ & 6.41 & 14.28 & 6.08 & 13.21 \\
\hline & & $15-30$ & 7.15 & 14.68 & 7.01 & 14.08 \\
\hline & & $30-60$ & 8.88 & 15.24 & 7.54 & 15.04 \\
\hline & \multirow{4}{*}{$\begin{array}{l}\text { Ammonium } \\
\text { sulphate }\end{array}$} & $0-15$ & 6.34 & 14.45 & 6.04 & 13.45 \\
\hline & & $15-30$ & 7.11 & 14.44 & 7.11 & 13.54 \\
\hline & & $30-60$ & 8.99 & 15.32 & 7.12 & 14.89 \\
\hline & & $0-15$ & 6.32 & 14.21 & 5.88 & 13.43 \\
\hline & \multirow{2}{*}{$\begin{array}{l}\text { Ammonia gas } \\
\text { injection }\end{array}$} & $15-30$ & 7.12 & 14.33 & 6.12 & 13.66 \\
\hline & & $30-60$ & 8.87 & 15.43 & 7.21 & 14.87 \\
\hline \multirow{9}{*}{$\begin{array}{l}\text { Mole drains in } \\
\text { two directions } \\
\text { (net) with open } \\
\text { drainage }\end{array}$} & \multirow{3}{*}{ Urea } & $0-15$ & 6.04 & 13.54 & 5.17 & 13.24 \\
\hline & & $15-30$ & 6.14 & 14.12 & 5.37 & 13.54 \\
\hline & & $30-60$ & 7.17 & 15.02 & 6.47 & 14.32 \\
\hline & \multirow{3}{*}{$\begin{array}{l}\text { Ammonium } \\
\text { sulphate }\end{array}$} & $0-15$ & 5.49 & 13.24 & 5.12 & 13.11 \\
\hline & & $15-30$ & 6.53 & 14.55 & 5.14 & 13.12 \\
\hline & & $30-60$ & 7.14 & 15.12 & 6.41 & 14.62 \\
\hline & \multirow{3}{*}{$\begin{array}{l}\text { Ammonia gas } \\
\text { injection }\end{array}$} & $0-15$ & 5.74 & 13.65 & 5.04 & 13.04 \\
\hline & & $15-30$ & 6.54 & 13.87 & 5.17 & 13.31 \\
\hline & & $30-60$ & 7.04 & 14.85 & 6.39 & 14.76 \\
\hline
\end{tabular}




\section{Bulk density and total porosity of the soil}

One of the most parameters that are responsible for soil quality, water, air and heat regimes is soil bulk density (Page et al., 1982). Soil bulk density increased with depth as a result of increasing compaction, (Table 4). Application of mole with open drainage reduced soil bulk density, especially after the second season. Values of soil bulk density with open drainage without mole drains are relatively high (varied from 1.26 to $1.42 \mathrm{Mg} / \mathrm{m}^{3}$ ) comparing with open drainage with mole drains (varied from 1.07 to $1.35 \mathrm{Mg} / \mathrm{m}^{3}$ ). These results might be explained by moling impacts on soil bulk density particularly above and around mole depths. It could be attributed to the effects of moling on breaking soil clods and bigger granular into smaller crumbs as well as breaking and cracking the compacted layers, in addition to increasing sodium leaching from the soil layers which increase $\mathrm{Ca}$ : $\mathrm{Na}$ ratio on clay surfaces (Abdel-Mawgoud et al., 2003 and ElSanat, 2018). Data also showed that, the using of mole drains in two directions as (network) with open drainage are superior to mole drains in one direction with open drainage on reducing soil bulk density. The mean values of soil bulk density were 1.17 and $1.23 \mathrm{Mg} / \mathrm{m}^{3}$ in the first season and were 1.18 and $1.23 \mathrm{Mg} / \mathrm{m}^{3}$ in the second season for two directions (net) and one direction, respectively. Similar results were reported by ElHenawy et al. (2016). Soil porosity values showed almost an opposite trend to that happened with bulk density. The application of mole drains in one and two directions with open drainage enhanced soil porosity. (Jodi DeJong, 2004 and Antar et al., 2016) stated that the theory behind mole drain and subsoiling are to shatter a deep compacted layer in the soil to increase water movement, increase total porosity, create better aeration for the rhizosphere and increase the availability of nutrients for plant growth. On the other hand, bulk density and total porosity of the soil (Table 4) are not affected by nitrogen fertilizer sources (urea, ammonium sulphate and ammonia gas).

TABLE 4. Soil bulk density and total porosity as influenced by different treatments after the first and second seasons from rice cultivation

\begin{tabular}{|c|c|c|c|c|c|c|}
\hline \multirow{2}{*}{\multicolumn{2}{|c|}{ Treatments }} & \multirow{3}{*}{$\begin{array}{c}\begin{array}{c}\text { Soil depth } \\
\text { (cm) }\end{array} \\
0-15\end{array}$} & \multicolumn{2}{|c|}{ After first season } & \multicolumn{2}{|c|}{ After second season } \\
\hline & & & Soil bulk density & Porosity & Soil bulk density & Porosity \\
\hline \multirow{9}{*}{$\begin{array}{l}\text { Open drainage } \\
\text { without mole } \\
\text { drains }\end{array}$} & \multirow{3}{*}{ Urea } & & 1.26 & 52.45 & 1.27 & 52.08 \\
\hline & & $15-30$ & 1.33 & 49.81 & 1.32 & 50.19 \\
\hline & & $30-60$ & 1.41 & 46.79 & 1.4 & 47.17 \\
\hline & \multirow{3}{*}{$\begin{array}{l}\text { Ammonium } \\
\text { sulphate }\end{array}$} & $0-15$ & 1.29 & 51.32 & 1.27 & 52.08 \\
\hline & & $15-30$ & 1.32 & 50.19 & 1.32 & 50.19 \\
\hline & & $30-60$ & 1.39 & 47.55 & 1.42 & 46.42 \\
\hline & \multirow{3}{*}{$\begin{array}{l}\text { Ammonia gas } \\
\text { injection }\end{array}$} & $0-15$ & 1.28 & 51.70 & 1.27 & 52.08 \\
\hline & & $15-30$ & 1.31 & 50.57 & 1.31 & 50.57 \\
\hline & & $30-60$ & 1.4 & 47.17 & 1.39 & 47.55 \\
\hline \multirow{10}{*}{$\begin{array}{l}\text { Mole drains in } \\
\text { one direction } \\
\text { with open } \\
\text { drainage }\end{array}$} & \multirow{3}{*}{ Urea } & $0-15$ & 1.18 & 55.47 & 1.18 & 55.47 \\
\hline & & $15-30$ & 1.24 & 53.21 & 1.21 & 54.34 \\
\hline & & $30-60$ & 1.25 & 52.83 & 1.29 & 51.32 \\
\hline & \multirow{3}{*}{$\begin{array}{l}\text { Ammonium } \\
\text { sulphate }\end{array}$} & $0-15$ & 1.15 & 56.60 & 1.15 & 56.60 \\
\hline & & $15-30$ & 1.24 & 53.21 & 1.23 & 53.58 \\
\hline & & $30-60$ & 1.32 & 50.19 & 1.31 & 50.57 \\
\hline & \multirow{4}{*}{$\begin{array}{l}\text { Ammonia gas } \\
\text { injection }\end{array}$} & $0-15$ & 1.12 & 57.74 & 1.09 & 58.87 \\
\hline & & $15-30$ & 1.22 & 53.96 & 1.23 & 53.58 \\
\hline & & $30-60$ & 1.33 & 49.81 & 1.35 & 49.06 \\
\hline & & $0-15$ & 1.12 & 57.74 & 1.12 & 57.74 \\
\hline \multirow{8}{*}{$\begin{array}{l}\text { Mole drains in } \\
\text { two directions } \\
\text { (net) with open } \\
\text { drainage }\end{array}$} & \multirow[t]{2}{*}{ Urea } & $15-30$ & 1.16 & 56.23 & 1.16 & 56.23 \\
\hline & & $30-60$ & 1.25 & 52.83 & 1.26 & 52.45 \\
\hline & \multirow{3}{*}{$\begin{array}{l}\text { Ammonium } \\
\text { sulphate }\end{array}$} & $0-15$ & 1.07 & 59.62 & 1.12 & 57.74 \\
\hline & & $15-30$ & 1.18 & 55.47 & 1.16 & 56.23 \\
\hline & & $30-60$ & 1.28 & 51.70 & 1.28 & 51.70 \\
\hline & \multirow{3}{*}{$\begin{array}{l}\text { Ammonia gas } \\
\text { injection }\end{array}$} & $0-15$ & 1.11 & 58.11 & $1 . .07$ & 59.62 \\
\hline & & $15-30$ & 1.19 & 55.09 & 1.17 & 55.85 \\
\hline & & $30-60$ & 1.21 & 54.34 & 1.26 & 52.45 \\
\hline
\end{tabular}


Infiltration rate (BIR) and cumulative infiltration

Data showed in Table (5) indicated that, basic infiltration rate (BIR) and cumulative infiltration values increased after one and two seasons due to mole application with open drainage. The values of basic infiltration rate and cumulative infiltration depth under open drainage without injection of mole varied from 0.56 to $0.60 \mathrm{~cm}$ $\mathrm{hr}^{-1}$ and 6.64 to $6.87 \mathrm{~cm}$, respectively. While, after mole with open drainage (after one and two seasons) the values of basic and cumulative infiltration ranged from 0.84 to $0.98 \mathrm{~cm} \mathrm{hr}^{-1}$ and 10.86 to $12.24 \mathrm{~cm}$, respectively. This may be attributed to mole drain that dried the top surface layer forming the shrinkage of clay particles and water ways to facilitate water movement into mole line (El-Sanat, 2018). Results also (Table 5) showed that, the implementation of mole drains in two directions as (network) with open drainage caused somewhat higher of basic infiltration rate and cumulative infiltration than mole drains in one direction with open drainage. The overall average values of basic infiltration rate were 0.89 and $0.93 \mathrm{cmhr}^{-1}$ for one direction and two directions, respectively. The corresponding values of cumulative infiltration were 11.24 and 11.84 $\mathrm{cm}$ for one and two directions, respectively. This is mainly due to swelling and shrinkage, cycles which improved soil structure (El-Sanat, 2018). Results also (Table 5) showed that, values of basic infiltration rate and cumulative infiltration after the second season from using mole drains with open drainage were somewhat lower than the first season.

Results in Table (5) showed that, infiltration rate and cumulative infiltration values do not affect by nitrogen fertilizer sources (urea, ammonium sulphate and ammonia gas).

TABLE 5. Basic infiltration rate $\left(\mathrm{cmh}^{-1}\right)$ and cumulative infiltration $(\mathrm{cm})$ after the first and second seasons as affected by treatments application

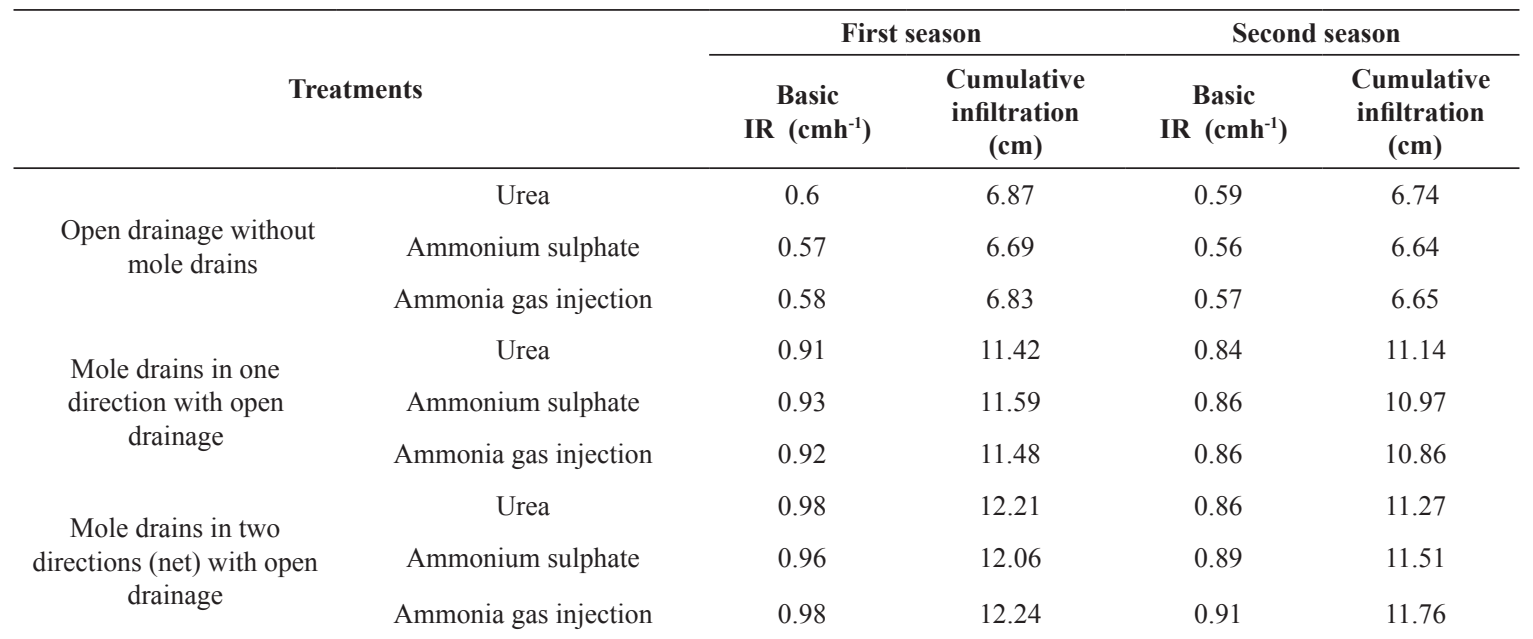

\section{Soil penetration resistance}

Results in Fig.1 showed that soil penetration resistance (SPR) values decreased after one and two seasons from injection of mole with open drainage. The values of Soil penetration resistance under open drainage without inserting of mole varied from 1.90 to $1.95 \mathrm{M}$ Pa while, after mole inserting with open drainage the values ranged from 1.2 to $1.65 \mathrm{M} \mathrm{Pa}$ (after one and two seasons). This means that mole drains effect was more superiority on reducing soil penetration resistance. It could be attributed to the effects of moling on breaking soil clods and bigger granular into smaller crumbs as well as breaking and cracking the compacted layers (El-Henawy et al., 2016). Results also in (Fig. 1) showed that,

the inserting of mole drains in two directions as (network) with open drainage caused somewhat lower of soil penetration resistance than mole drains in one direction with open drainage. The overall average values of soil penetration resistance were 1.59 and $1.29 \mathrm{MPa}$ for one direction and two directions, respectively. This is due to swelling and shrinkage, cycles which improved soil structure (El-Sanat, 2018). Results also showed that, values of soil penetration resistance after the second season from inserting mole drains with open drainage were somewhat higher than the first season (Fig 1). Results show that, no obvious trend with soil penetration resistance values under $\mathrm{N}$-fertilizersources. 
A)

B)

C)

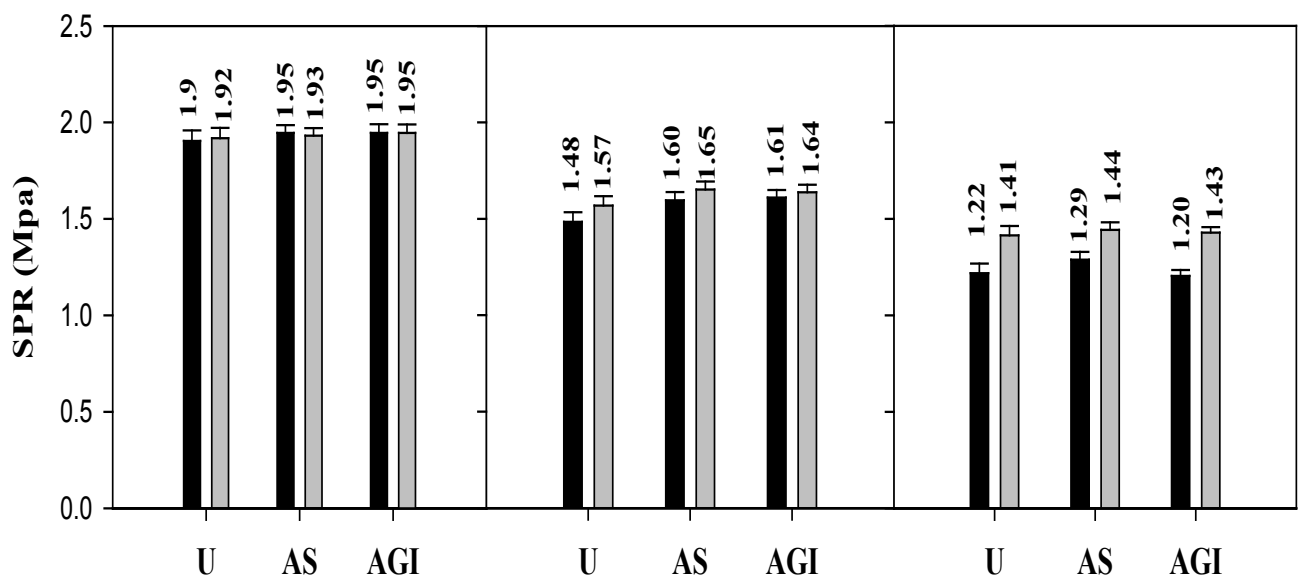

Nitrogen fertilizer sources

Fig.1. Penetration resistance (M Pa) of soil subjected to different drainage systems, e.g. open drainage without mole drains (A), mole drains one in direction with open drainage (B), and mole drains in two directions with open drainage $(C)$ as well as different nitrogen fertilizer sources e.g. urea (U), ammonium sulphate (AS) and ammonia gas injection (AGI) through two growing seasons, first season (black bars) and second season (grey bars)

\section{Rice yields and N-uptake}

Data in Table 6 indicated that, the application of mole with open drainage as well as ammonia gas injection caused significant increases of rice yields, especially in the second season. The yields are increased which resulted in improving soil properties as affected by mole drains application. It can be concluded that heavy clay salt affected soils could have good productivity with the execution ofmole application with open drainage and ammonia gas injection (El-Sanat, 2018). The optimum Rice grains yieldachieved by application of mole with open drainage (in one and two directions) comparing open drainage without mole. The increases of rice grains yield were 12.93 and $14.55 \%$ in the first season and 17.92 and $18.79 \%$ in the second season forapplication of mole with open drainagein one and two directions, respectively over than open drainage without mole. The corresponding values of rice straw yield were 20 and $20 \mathrm{~kg}$ fed. ${ }^{-1}$ in the first season and 50 and $60 \mathrm{~kg}$ fed. ${ }^{-1}$ in the second season, respectively (one feddan $=4200 \mathrm{~m}^{2}$ ). The increases of rice yields are more pronounced with application of mole with open drainagecompared to open drainage without mole. Such findings may be attributed to the effect of moling on improving soil properties (Antaret al.2012). It can be concluded that under such conditions the application of mole with open drainageare the most effective treatments that ameliorate saline sodic clay soil. Similar results were obtained by Lickacz (1993) and Antar et al.(2016).
Results showed that the injection of anhydrous ammonia before sowing with and without mole are superior in improving rice yield as compared to mineral nitrogen source (ammonium sulphate and urea) in both seasons (Table 6). Rice grains yield were 2.39 and $2.41 \mathrm{Mg}$ fed. ${ }^{-1}$ with anhydrous ammonia while, it were 2.27 and $2.28 \mathrm{Mg} \mathrm{fed}^{-1}$ with ammonium sulphate, and were 2.20 and $2.19 \mathrm{Mg}$ fed. ${ }^{-1}$ with urea for the first and second seasons, respectively under open drainage without mole drains. Also, anhydrous ammonia injection caused higher in rice grains yieldthan ammonium sulphate and urea, respectively by 240 and $230 \mathrm{~kg}$ fed. ${ }^{-1}$ in the first season and 180 and $230 \mathrm{~kg}$ fed. ${ }^{-1}$ in the second season under mole one direction with open drainage. The corresponding values were 170 and $230 \mathrm{~kg} \mathrm{fed}^{-1}$ in the first season and 240 and $280 \mathrm{~kg} \mathrm{fed}^{-1}$ in the second season under mole two directions with open drainage. Generally, ammonia gas injection caused increase of rice grains yield about6.39and $8.43 \%$ in the first season and 6.83 and $9.65 \%$ in the second season compared to ammonium sulphate, and urea, respectively. Abd El-Kader (2002) reported that when the anhydrous ammonia injected before sowing, produced higher yield and minerals uptake than other nitrogen sources. It can be concluded that under such conditions the moling is the most effective treatments that ameliorate saline sodic clay soil. 
TABLE 6. Effect of different studied treatments on rice yields $\left(\mathrm{Mg} \mathrm{fed}^{-1}\right)$

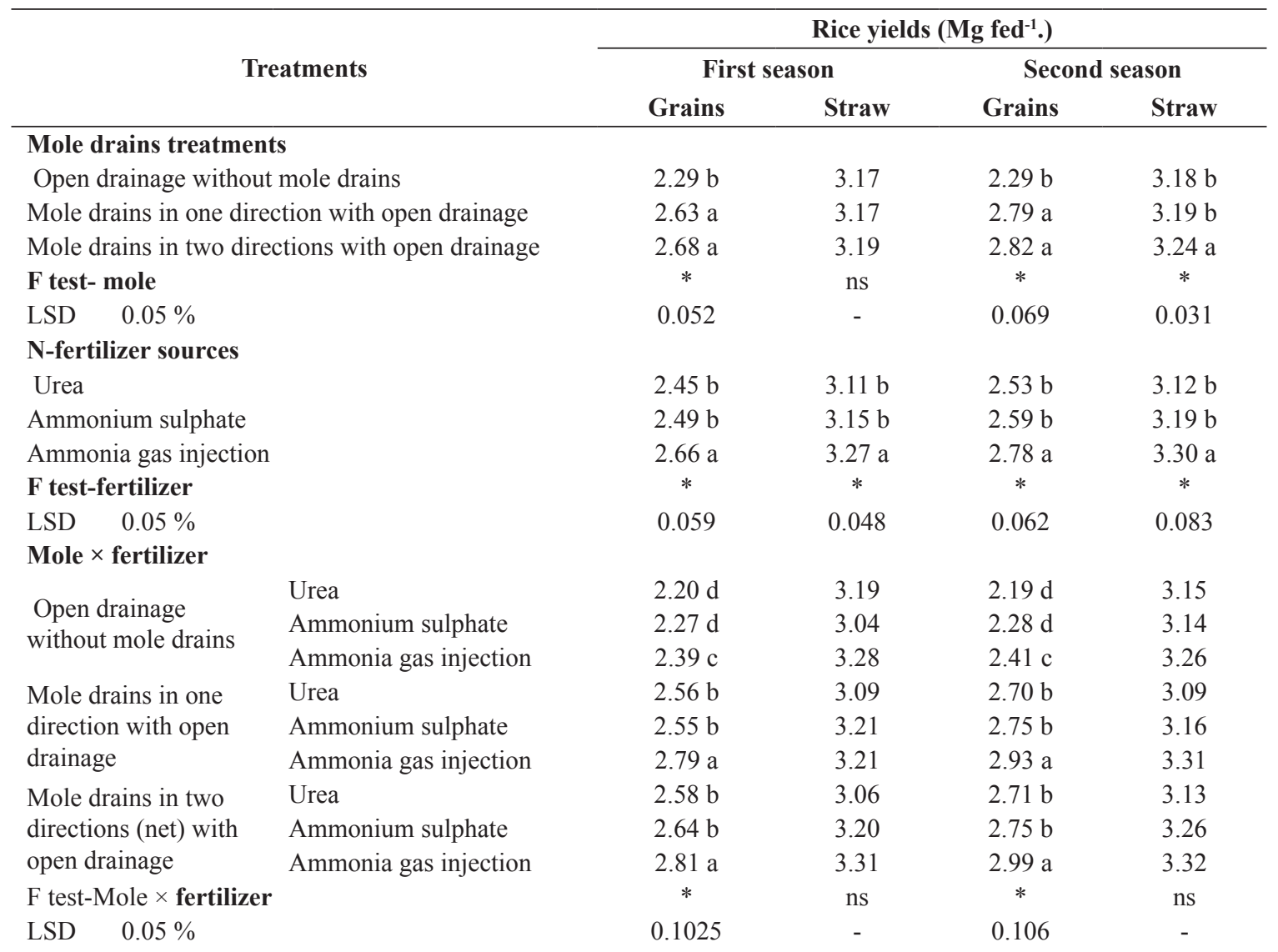

Data in Table 7 showed that, N-uptake by rice were parallel to the yields results in both seasons. Where as, treatments application caused significant increases of N-uptake of rice grains yield. Data showed that, the low values of N-uptake by grains of rice (varied from 29.36 to $35.65 \mathrm{kgfed}^{-1}$ ) were observed with open drainage without mole drains, and the high values (varied from 35.35 to 47.79 kgfed. $^{-1}$ ) were found with open drainage with mole drains in both seasons. Results indicate that, N-uptake by ricearemore pronounced with anhydrous ammonia injected compared to mineral nitrogen source. Also, mole drains with anhydrous ammoniais superior tomole with other nitrogen sourcesin enhancingof $\mathrm{N}$-uptake by rice grain yield. Generally, the mean values of $\mathrm{N}$-uptake by rice grains yield were $40.83,35.54$ and $33.50 \mathrm{~kg} \mathrm{fed}^{-1}$ in the first season and 43.06, 37.13 and $35.15 \mathrm{~kg} \mathrm{fed} \cdot{ }^{-1}$ in the second season for anhydrous ammonia, ammonium sulphate, and urea, respectively. Abd El-Kader (2002) reported that when the anhydrous ammonia injected before sowing, gave higher yield and minerals uptake than other nitrogen sources.

Water applied and productivity of irrigation water Data presented in Table 8 indicated that the application of mole drains in one and two directions with open drainage had received the highest amount of irrigation water compared to without mole drains. This is due to, under mole drains noticed, high amount of drainage water was discharged also application of mole drains with open drainage gave the top soil layer a chance to dry and permitted for shrinkage and formation of water passage ways which allowed a rather easier movement of water into mole line (Antar et al., 2016). On the other hand, open drainage without mole stored more water. Also, water amount under mole treatments in the first season were higher than second season. This due to, in the second season the increase in setting of trench backfill after one year from digging and backfilling in such low permeability heavy textured soil (El-Hamchary et al., 1989). The average values of AW were 5713,6423 and $6453 \mathrm{~m}^{3}$ fed. ${ }^{-1}$ in the first season and 5713,6153 and $6177 \mathrm{~m}^{3}$ fed. ${ }^{-1}$ in the second season for open drainage without mole drains, mole drains in one direction and mole drains in two directions, respectively. Also, data showed that nitrogen fertilizer sources (urea, ammonium sulphate and ammonia gas) had no clear effect on amount of irrigation water for both seasons. 
TABLE 7. N-uptake of rice $\left(\mathrm{kg} \mathrm{fed}^{-1}\right)$, with different studied treatments

\begin{tabular}{|c|c|c|c|c|c|c|c|}
\hline & & \multicolumn{6}{|c|}{$\mathrm{N}$-uptake of rice yields (kgfed-1) } \\
\hline \multicolumn{2}{|c|}{ Treatments } & \multicolumn{2}{|c|}{ First season } & \multicolumn{2}{|c|}{ Second season } & \multicolumn{2}{|c|}{ Overall mean } \\
\hline \multicolumn{8}{|l|}{ Mole drains treatments } \\
\hline \multicolumn{2}{|c|}{ Open drainage without mole drains } & $31.73 \mathrm{~b}$ & 7.85 & $32.15 \mathrm{~b}$ & $7.88 \mathrm{c}$ & 31.94 & 7.87 \\
\hline \multicolumn{2}{|c|}{ Mole drains in two directions with open drainage } & $39.62 \mathrm{a}$ & 8.10 & $41.51 \mathrm{a}$ & $8.44 \mathrm{a}$ & 40.57 & 8.27 \\
\hline \multicolumn{2}{|c|}{ F test- mole } & * & ns & * & $*$ & & \\
\hline \multicolumn{2}{|l|}{ LSD $0.05 \%$} & 1.459 & - & 1.349 & 0.118 & & \\
\hline \multicolumn{8}{|l|}{ N-fertilizer sources } \\
\hline \multicolumn{2}{|l|}{ F test- mole } & $*$ & $*$ & $*$ & $*$ & & \\
\hline \multicolumn{2}{|l|}{ LSD $0.05 \%$} & 0.962 & 0.4397 & 1.035 & 0.0695 & & \\
\hline \multicolumn{8}{|l|}{ Mole $\times$ fertilizer } \\
\hline \multirow{3}{*}{$\begin{array}{l}\text { Open drainage without } \\
\text { mole drains }\end{array}$} & Urea & $29.50 \mathrm{e}$ & $7.90 \mathrm{~b}$ & $29.36 \mathrm{~g}$ & $7.79 \mathrm{de}$ & 29.43 & 7.85 \\
\hline & Ammonium sulphate & $30.61 \mathrm{e}$ & $7.53 \mathrm{~b}$ & $31.44 \mathrm{f}$ & $7.79 \mathrm{de}$ & 31.03 & 7.66 \\
\hline & Ammonia gas injection & $35.09 \mathrm{~d}$ & $8.13 \mathrm{ab}$ & $35.65 \mathrm{e}$ & $8.06 \mathrm{c}$ & 35.37 & 8.10 \\
\hline \multirow{2}{*}{$\begin{array}{l}\text { Mole drains in one } \\
\text { direction with open } \\
\text { drainage }\end{array}$} & Urea & $35.35 \mathrm{~d}$ & $7.64 \mathrm{~b}$ & $38.92 \mathrm{~cd}$ & $7.66 \mathrm{e}$ & 37.14 & 7.65 \\
\hline & Ammonium sulphate & $37.24 \mathrm{bc}$ & $7.94 \mathrm{~b}$ & $40.38 \mathrm{c}$ & $7.81 \mathrm{~d}$ & 38.81 & 7.88 \\
\hline
\end{tabular}

TABLE 8. Water applied $\left(\mathrm{m}^{3} \mathrm{fed} .^{-1}\right)$ and productivity of irrigation water (PIW, $\left.\mathrm{Kgm}^{-3}\right)$ for both grain and straw yields of rice crop as affected by different treatments

\begin{tabular}{|c|c|c|c|c|c|c|c|}
\hline & & \multicolumn{2}{|c|}{ Water applied $\mathbf{m}^{3} \mathbf{f e d}^{-1}$} & \multicolumn{4}{|c|}{ Productivity of irrigation water $\left(\mathrm{Kgm}^{-3}\right)$} \\
\hline \multicolumn{2}{|c|}{ Treatments } & \multirow{2}{*}{$\begin{array}{c}1^{\text {st }} \\
\text { season }\end{array}$} & \multirow{2}{*}{$\begin{array}{c}2^{\text {nd }} \\
\text { season }\end{array}$} & \multicolumn{2}{|c|}{ Grain yield } & \multicolumn{2}{|c|}{ Straw yield } \\
\hline & & & & $1^{\text {st }}$ & $2^{\text {nd }}$ & $1^{\text {st }}$ & $2^{\text {nd }}$ \\
\hline \multirow{3}{*}{$\begin{array}{l}\text { Open drainage } \\
\text { without mole } \\
\text { drains }\end{array}$} & Urea & 5730 & 5740 & 0.38 & 0.38 & 0.56 & 0.55 \\
\hline & Ammonium sulphate & 5710 & 5700 & 0.40 & 0.4 & 0.53 & 0.55 \\
\hline & Ammonia gas injection & 5700 & 5700 & 0.42 & 0.42 & 0.58 & 0.57 \\
\hline \multirow{3}{*}{$\begin{array}{l}\text { Mole drains in one } \\
\text { direction with open } \\
\text { drainage }\end{array}$} & Urea & 6460 & 6150 & 0.40 & 0.44 & 0.48 & 0.50 \\
\hline & Ammonium sulphate & 6410 & 6160 & 0.40 & 0.45 & 0.50 & 0.51 \\
\hline & Ammonia gas injection & 6400 & 6150 & 0.44 & 0.48 & 0.50 & 0.54 \\
\hline \multirow{3}{*}{$\begin{array}{l}\text { Mole drains in two } \\
\text { directions with } \\
\text { open drainage }\end{array}$} & Urea & 6450 & 6170 & 0.40 & 0.44 & 0.47 & 0.51 \\
\hline & Ammonium sulphate & 6460 & 6180 & 0.41 & 0.44 & 0.50 & 0.53 \\
\hline & Ammonia gas injection & 6450 & 6180 & 0.44 & 0.48 & 0.51 & 0.54 \\
\hline
\end{tabular}


Productivity of irrigation wateris generally defined as crop yield per cubic meter of water applied (Ali et al., 2007). Data presented in Table 8 illustrated that the values of PIW for rice grain and straw yields were greatly influenced by different treatments in both seasons. Results in Table 8 revealed that, the low values of PIW for grain yield (varied from 0.38 to $0.42 \mathrm{~kg} \mathrm{~m}^{-3}$ ) were found with open drainage without mole drains, and the high values (varied from 0.40 to $0.48 \mathrm{~kg} \mathrm{~m}^{-3}$ ) were found with open drainage with mole drains in both seasons. Results indicate that, productivity of irrigation water $\left(\mathrm{kg} \mathrm{m}^{-3}\right)$ are more pronounced with anhydrous ammonia injected compared to mineral nitrogen sources. The highest values of PIW were achieved with anhydrous ammonia injected followed by ammonium sulphate, while, the lowest ones was produced by urea fertilizer in both seasons.

With respect to PIW for rice straw yield, data showed that values of PIW were ranged from 0.47 to $0.58 \mathrm{~kg} \mathrm{~m}^{-3}$ in the first season, while the corresponding values of PIW ranged from 0.50 to $0.57 \mathrm{~kg} \mathrm{~m}^{-3}$ in the second season since it was recorded with open drainage with mole drains. Also, data indicated that the highest values of PIW were achieved with anhydrous ammonia injected compared to mineral nitrogen source in both seasons. On the other hand, values of PIW for rice straw yield under open drainage without mole drains were relatively somewhat high compared to mole drains. This is due to the less amount of irrigation water with open drains without mole.

\section{Fertilizer application efficiency (FAE)}

Fertilizer application efficiency reflects the ability of the plants to utilize the soil fertilization. Soil fertilization consists of artificial application plus the base content of specific element before cultivation (Brentrap and Palliere, 2010). As shown in Table 9, application of mole with open drainage had the highest FAE of nitrogen. This is due to the effect of mole drains on improving soil properties which affects water-air relationships in the root zone and its effect on mobility of nutrients to the plant roots (Aiad et al., 2012). Also, anhydrous ammonia is superior to other nitrogen sources in enhancing of nitrogen application efficiency for rice yields with and without mole application. Generally, the mean values of nitrogen application efficiency for rice yields were $77.90,69.95$ and $66.15 \%$ in the first season and $80.04,71.66$ and $68.93 \%$ in the second season for anhydrous ammonia, ammonium sulphate, and urea, respectively. This may be due to the slight losses of $\mathrm{N}$-fertilizer under anhydrous ammonia comparing with mineral $\mathrm{N}$-fertilizer (Antar and Awad, 2014). Also, mole drains with anhydrous ammonia is superior to mole with other nitrogen sources in enhancing of nitrogen application efficiency for rice yields especially in the second season.

\section{TABLE 9. Nitrogen application efficiency (NAE; \%)with different studied treatments}

\begin{tabular}{|c|c|c|c|c|c|c|c|}
\hline \multirow{3}{*}{\multicolumn{2}{|c|}{ Treatments }} & \multicolumn{6}{|c|}{ Nitrogen application efficiency (\%) } \\
\hline & & \multicolumn{3}{|c|}{ First season } & \multicolumn{3}{|c|}{ Second season } \\
\hline & & $\begin{array}{l}\mathrm{N} \text {-Applied }+ \\
\text { native kgfed }^{-1}\end{array}$ & $\begin{array}{c}\text { N-Uptake } \\
\text { +residual } \\
\text { kgfed }^{-1} \\
\end{array}$ & NAE $\%$ & $\begin{array}{c}\text { N-Applied+ } \\
\text { native } \\
\text { kgfed }^{-1} \\
\end{array}$ & $\begin{array}{c}\text { N-Uptake } \\
\text { +residual } \\
\text { kgfed }^{-1} \\
\end{array}$ & NAE\% \\
\hline \multirow{3}{*}{$\begin{array}{l}\text { Open drainage } \\
\text { without mole } \\
\text { drains }\end{array}$} & Urea & 102.08 & 68.76 & 67.36 & 105.57 & 71.06 & 67.31 \\
\hline & Ammonium sulphate & 102.08 & 69.01 & 67.60 & 105.87 & 69.04 & 65.21 \\
\hline & $\begin{array}{l}\text { Ammonia gas } \\
\text { injection }\end{array}$ & 102.08 & 76.25 & 74.70 & 106.57 & 78.15 & 73.33 \\
\hline \multirow{3}{*}{$\begin{array}{l}\text { Mole drains in } \\
\text { one direction } \\
\text { with open } \\
\text { drainage }\end{array}$} & Urea & 102.08 & 68.91 & 67.51 & 102.49 & 72.44 & 70.68 \\
\hline & Ammonium sulphate & 102.08 & 72.63 & 71.15 & 102.29 & 77.71 & 75.97 \\
\hline & $\begin{array}{l}\text { Ammonia gas } \\
\text { injection }\end{array}$ & 102.08 & 80.97 & 79.32 & 104.91 & 86.98 & 82.91 \\
\hline \multirow{3}{*}{$\begin{array}{l}\text { Mole drains in } \\
\text { two directions } \\
\text { with open } \\
\text { drainage }\end{array}$} & Urea & 102.08 & 64.92 & 63.60 & 99.00 & 68.10 & 68.79 \\
\hline & Ammonium sulphate & 102.08 & 72.58 & 71.10 & 100.95 & 74.51 & 73.81 \\
\hline & $\begin{array}{l}\text { Ammonia gas } \\
\text { injection }\end{array}$ & 102.08 & 81.35 & 79.69 & 101.13 & 84.84 & 83.89 \\
\hline \multicolumn{8}{|c|}{ Average of $\mathrm{N}$-fertilizer sources } \\
\hline \multicolumn{2}{|l|}{ Urea } & 102.08 & 67.53 & 66.15 & 102.35 & 70.53 & 68.93 \\
\hline \multicolumn{2}{|c|}{ Ammonium sulphate } & 102.08 & 71.41 & 69.95 & 103.04 & 73.75 & 71.66 \\
\hline \multicolumn{2}{|c|}{ Ammonia gas injection } & 102.08 & 79.52 & 77.90 & 104.20 & 83.32 & 80.04 \\
\hline
\end{tabular}


Economic evaluation (Profitability)

Economic analysis and evaluation were conducted to test the different treatments which include the cost, return and effectiveness of treatments. Crop enterprise budget is a system for presenting data about a specified enterprise on the cost of input resources (Including land preparation, labors, machine, ...etc.)as well as on the value of output for a given area of land, as shown in Table 10.

TABLE 10. Agricultural operation costs and labor wages for rice in summer seasons of 2016 and 2017 according to the local market price (LE)

\begin{tabular}{|c|c|c|c|c|c|}
\hline \multirow{2}{*}{\multicolumn{4}{|c|}{ Items }} & \multicolumn{2}{|c|}{ Price (LE) according to the local market } \\
\hline & & & & First season & second season \\
\hline \multirow[t]{17}{*}{ Costs } & \multirow{10}{*}{ 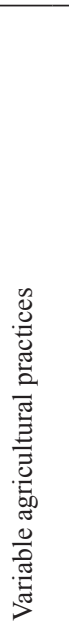 } & \multirow{5}{*}{ 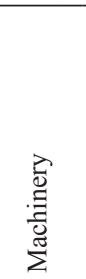 } & Tillage $2 \mathrm{hr} \mathrm{fed}^{-1}$ & 40 (LE. $\mathrm{hr}^{-1}$ ) & $50\left(\right.$ LE. $\left.\mathrm{hr}^{-1}\right)$ \\
\hline & & & Irrigation & $250\left(\right.$ LE. fed $\left.{ }^{-1}\right)$ & $270\left(\right.$ LE. fed $\left.{ }^{-1}\right)$ \\
\hline & & & Harvesting & $360\left(\right.$ LE. fed $\left.{ }^{-1}\right)$ & $390\left(\right.$ LE. fed $\left.^{-1}\right)$ \\
\hline & & & Weed control & $100\left(\right.$ LE. fed $\left.{ }^{-1}\right)$ & $100\left(\right.$ LE. fed $\left.{ }^{-1}\right)$ \\
\hline & & & Land leveling $\left(1.5 \mathrm{hr} \mathrm{fed}^{-1}\right)$ & $40\left(\right.$ LE. $\left.\mathrm{hr}^{-1}\right)$ & $50\left(\right.$ LE. $\left.\mathrm{hr}^{-1}\right)$ \\
\hline & & \multirow{4}{*}{ 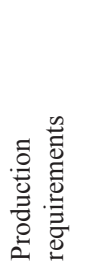 } & Gypsum $\left(1.5 \mathrm{Mg}\right.$ fed $\left.^{-1}\right)$ & $100\left(\right.$ LE. $\left.\mathrm{Mg}^{-1}\right)$ & $100\left(\right.$ LE. $\left.\mathrm{Mg}^{-1}\right)$ \\
\hline & & & pesticides & $75\left(\right.$ LE. fed $\left.^{-1}\right)$ & 75 (LE. fed $\left.^{-1}\right)$ \\
\hline & & & Seeds $\left(60 \mathrm{kgfed}^{-1}\right)$ & $3750\left(\mathrm{LE}_{\mathrm{Mg}} \mathrm{Mg}^{-1}\right)$ & $4250\left(\mathrm{LE}_{\mathrm{Mg}} \mathrm{Mg}^{-1}\right)$ \\
\hline & & & $\begin{array}{l}\text { Ca-superphosphate }\left(50 \text { kgfed. }^{-1}, 15.5 \% \mathrm{P}_{2} \mathrm{O}_{5}\right)= \\
322.5 \mathrm{~kg} \text { fertilizer fed }\end{array}$ & $\begin{array}{l}400 \text { (LE. } \mathrm{Mg}^{-1} \text {, } \\
\text { fertilizer) }\end{array}$ & $\begin{array}{l}450 \text { ( } \mathrm{LE} . \mathrm{Mg}^{-1} \\
\text { fertilizer) }\end{array}$ \\
\hline & & \multicolumn{2}{|c|}{$\begin{array}{l}\text { Labor wages (transplanting, irrigation, harvesting, weed } \\
\text { control ....etc. }\end{array}$} & $1070\left(\right.$ LE. fed $\left.^{-1}\right)$ & $1140\left(\right.$ LE. fed $\left.{ }^{-1}\right)$ \\
\hline & \multicolumn{3}{|c|}{ Totalvariable costs of agricultural practices } & $2500\left(\right.$ LE. fed $\left.{ }^{-1}\right)$ & $2700\left(\right.$ LE. fed $\left.{ }^{-1}\right)$ \\
\hline & \multicolumn{3}{|c|}{ Land rent for summer seasons } & $2800\left(\right.$ LE. fed $\left.^{-1}\right)$ & $3000\left(\right.$ LE. fed $\left.^{-1}\right)$ \\
\hline & \multirow{2}{*}{\multicolumn{2}{|c|}{$\begin{array}{l}\text { Mole } \\
\text { drains }\end{array}$}} & Mole drains in one direction & $100\left(\right.$ LE. fed $\left.{ }^{-1}\right)$ & $100\left(\right.$ LE. fed $\left.{ }^{-1}\right)$ \\
\hline & & & Mole drains in two directions & $150\left(\right.$ LE. fed $\left.{ }^{-1}\right)$ & $150\left(\right.$ LE. fed $\left.{ }^{-1}\right)$ \\
\hline & \multirow{3}{*}{\multicolumn{2}{|c|}{ 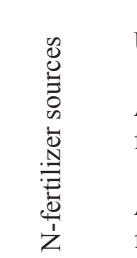 }} & Urea $75 \mathrm{kgNfed}^{-1}(46.5 \% \mathrm{~N})=161.3 \mathrm{~kg}$ fertilizer fed ${ }^{-1}$ & $\begin{array}{l}3720 \text { (LE. } \mathrm{Mg}^{-1} \\
\text { fertilizer) }\end{array}$ & $\begin{array}{l}4650\left(\mathrm{LE} . \mathrm{Mg}^{-1}\right. \\
\text { fertilizer })\end{array}$ \\
\hline & & & $\begin{array}{l}\text { Ammonium sulphate } 75 \mathrm{kgNfed}^{-1}(20.6 \% \mathrm{~N})=364 \mathrm{~kg} \\
\text { fertilizer fed }^{-1}\end{array}$ & $\begin{array}{l}1920\left(\mathrm{LE} \cdot \mathrm{Mg}^{-1},\right. \\
\text { fertilizer) }\end{array}$ & $\begin{array}{l}2200\left(\mathrm{LE} . \mathrm{Mg}^{-1}\right. \\
\text { fertilizer) }\end{array}$ \\
\hline & & & $\begin{array}{l}\text { Ammonia gas } 75 \mathrm{kgNfed}^{-1}(82 \% \mathrm{~N})=91.46 \mathrm{~kg} \\
\text { fertilizer fed } \mathrm{d}^{-1}\end{array}$ & $\begin{array}{l}6560 \text { (LE.Mg-1, } \\
\text { fertilizer) }\end{array}$ & $\begin{array}{l}8200 \text { (LE.Mg-1, } \\
\text { fertilizer) }\end{array}$ \\
\hline \multirow[t]{2}{*}{ Revenue } & \multirow{2}{*}{\multicolumn{2}{|c|}{$\begin{array}{l}\text { Yields } \\
\text { (Table 6) }\end{array}$}} & Grain yield & $3400\left(\mathrm{LEMg}^{-1}\right)$ & 3750(LE.Mg $\left.{ }^{-1}\right)$ \\
\hline & & & Straw yield & $100\left(\right.$ LE. $\left.\mathrm{Mg}^{-1}\right)$ & $\left.100\left(\text { LE. }^{-1}\right)^{-1}\right)$ \\
\hline
\end{tabular}

Data in Table 11 indicated that the lowest values of net return (LE fed ${ }^{-1}$ ), economic efficiency and net return from water unit $\left(\mathrm{LE} \mathrm{m}^{-3}\right)$ for both biological and grain yields were obtained with open drainage without mole drains, while, the highest values were achieved with application of mole drains with open drainage especially in the second season. It can be concluded that under such conditions of the current study, the application of mole drains with open drainage are the most economically effective treatments that ameliorate saline sodic clay soil which were led to increase the rice yields (Table 6), especially, in the second season. Anhydrous ammonia is surpassed to the other nitrogen sources in increment of net return (LE fed. ${ }^{-1}$ ), economic efficiency and net return from water unit (L.E. $\mathrm{m}^{-3}$ ) for rice yields with and without mole drain. The maximum values of economic efficiency ( 0.63 and 0.75 for biological yield and 0.58 and 0.70 for grain yield for first and second seasons, respectively) and net return from water unit $\left(0.59\right.$ and 0.80 L.E. ${ }^{-3}$ for biological yield and 0.54 and 0.75 L.E.m ${ }^{-3}$ for grain yield for first and second seasons, respectively) were recorded with application of mole drains in two directions with open drainage under anhydrous 
ammonia. The minimum values of economic efficiency $(0.32$ and 0.32 for biological yield and 0.27 and 0.27 for grain yield for first and second seasons, respectively) and net return from water unit $\left(0.33\right.$ and $0.36 \mathrm{LE} \mathrm{m}^{-3}$ for biological yield and 0.28 and $0.31 \mathrm{LEm}^{-3}$ for grain yield for first and second seasons, respectively) were obtained with open drainage without mole under urea fertilizer.

TABLE 11. Values of total revenue, total cost, net return, economic efficiency and net return from water unit as affected by different treatments during the two growing seasons for rice yields

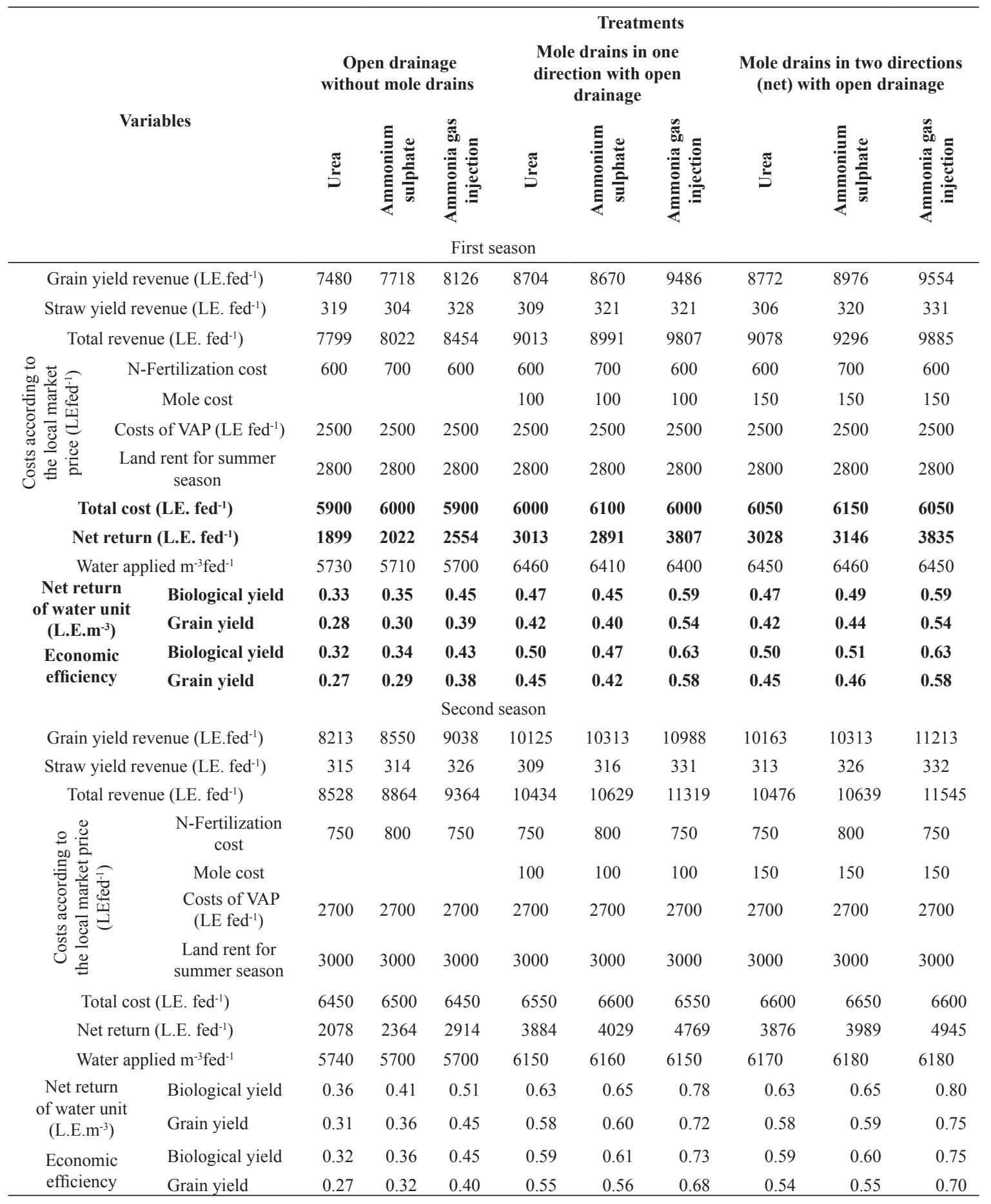

$V A P=$ variable costs of agricultural practices

-Net return: it can be calculated by deducting the total cost from the total return, $\left(\right.$ LEfed $\left.^{-1}\right)$

- Economic efficiency: it can be calculated by dividing the total seasonal net return on total seasonal cost

- Net return from water unit: it can be calculated by dividing seasonal net return (LE fed. $\left.{ }^{-1}\right)$ on seasonal water applied $\left(\mathrm{m}^{3}\right.$ fed. $\left.{ }^{-1}\right)$. 


\section{Conclusion}

Based on obtained results of the current study it can be concluded that mole drains along with open drainage had favorable effective to improve soil physio-chemical characteristics and increase crop production. Moreover, anhydrous ammonia injection before sowing with and without mole caused higher in yields, N-uptake and nitrogen application efficiency of rice grains than ammonium sulphate and urea. So, application of mole drains and / or ammonia gas injection were achieved the highest values of productivity of irrigation water, net return from water unit and economic efficiency for rice yields.

\section{References}

Abd El-Kader, G. Mona (2002) Response of growth and yield of wheat "cv. SED 57 "to Fe and $\mathrm{Zn}$ application under ammonia injection, $P h$. D Thesis, Fac. Agric. Moshtohor, Zagazig Univ., Egypt.

Abdel-Mawgoud A.S.A, , El Shewikh, M. B., AbdelAal, A. N. and Abdel-Khalik, M.I.I. (2003) Open drainage and moiling for desalinization of Salty Clay Soils of Northeastern Egypt. Presented at the 9th International Drainage Workshop, September $10-13,2003$, Utrecht, The Netherlands.

Aiad, M.A.F., Abd El-Aziz, M.A., Zamil, B.A.A. and Antar, A.S. (2012) Combating of soil deterioration at North Delta, Egypt. J. Agric. Res. Kafr El-Sheikh Univ., 38 (2), 322-341.

Ali, M.H., Hoque, M.R., Hassan, A.A. and Khair, A. (2007) Effect of deficit irrigation on yield water productivity, and economic returns of wheat. Agricultural Water Management, 92 (3), 151-161.

Ali, T. and Kahlown, M.A. (2001) Role of gypsum in amelioration of saline-sodic and sodicsoil. International Journal of Agriculture and Biology, 3 (3), 326-332.

Anon. (2001) Salt Contamination Assessment \& Remediation Guidelines.Environment Sciences Division Alberta Environment,(http://www.QOv. ab.ca/env/).

Antar A.S. and Awad, M.Y.M. (2014) Impact of nitrogen sources on nitrate losses into tile drain in clay soil under sugar beet crop.Middle East Journal of Agricultural Research, 3 (4), 936-942.

Antar, A.S., George, B.A., Shabana, M.A. , Atwa,A.I., Khalifa, H.E., Ramadan, H.M. and Swelam, A. (2016) Impact of Subsurface Drainage on Salinity Management in the Nile Delta, Egypt. $4^{\text {th }}$ AFRICAN

J. Sus. Agri. Sci. 44, No. 2 (2018)
REGIONAL CONFERENCE ON IRRIGATION AND DRAINAGE (ARCID) "Agricultural Land and Water Management for Sustainability under Climate Variability" Organized by The Egyptian National Committee on Irrigation and Drainage (ENCID) Aswan, Egypt April 26-28.

Antar, S. A., Mohamedin, A.A.M. and El-Meligy, A.M. (2012) Improving root zone and production of clay salt affected soil as a result of different subsurface tillage. $11^{\text {th }}$ ICID International Drainage Workshop on Agricultural Drainage Needs and Future Priorities. Cairo, Egypt September 23 - 27, 2012.

Arafat, S., Afify, A., Aboelghar, M. and Belal, A. (2010) Rice crop monitoring in Egyptian Nile Delta using Egyptsat-1 DATA. Joint U.S.- Egypt Workshop for Space Technology \& Geo-information for Sustainable Development, NARSS-Cairo, 2010

Atia , R.H., Knany, R.E., El-Saady, A.S.M. and Zidan, M.I ( 2007 ) Sugar beet response to nitrogen forms and rates under different tillage practices .expressed by polynomial quadratic equation. Egypt. J. Agric. Res. 85 (4), 1127-1139.

Bennett, D. L., George, R. and Russell, B., (2005) Mole drainage for increased productivity in the south west irrigation area. Department of Agriculture and Food, Western Australia, Perth. Bulletin, 4610.

Brentrap, F. and Palliere, C. (2010) Nitrogen Use Efficiency as an Agro Environmental Indicator. In Proceedings of the OECD Workshop on Agri environmental Indicators, March 23-26.Leysin, Switzerland.

Campbell, D.J. (1994) Determination and use of bulk density in relation to soil compaction.In:Soane and Ouwerk (Ed.) Soil Compaction in Crop Production. Elsever, London and Amsterdam.

Cottenie, A., Verloo, P.M., Kiekens, L., Velghe, G. and Camerlynck, R. (1982) Chemical Analysis of Plants and Soils. Lab. Anal. and Agrochem. State Univ., Gent. Belgium, Chapter 2 and 3, pp 14-54.

David Hopkins, Colac (2002) Managing Wet Soils: Mole Drainage. WWW.dse. Vic. Gov.

Duncan, D.B. (1955) Multiple range and multiple F-test Biometrics, 11, 1.

El-Hamchary, S. A., Ibrahim, M. M., Gaheen, S. A. and El-Gohary, E. A. (1989) Effects of subsoiling operation on the drainage response of heavy clay soil. J. Agric. Res. Tanta Unv., 15 (3), 535- 552.

El-Henawy A. S., Atta, M. Hamad and Antar, A.S. 
(2016)Impact of mole drains and n-fertilizer rates on some soil properties and sugar beet production in clay soil. International Journal of Advanced Research, Volume 4, Issue 6, 220-229.

El-Sanat, G.M.A. (2018) Impact of subsoiling, organic manure and nitrogen sources on some soil properties and sugar beet productivity. Menoufia J. Soil Sci., Vol. 3 February: 1 - 16.

FAO (2000) Fertilizers and their use, evaluation of fertilizer demonstrations.Apocket guide for extenstion officers. $4^{\text {th }}$ edition.Food and Aguiculture Organization of The United Nations, International Fertilizer Industry Association, Rome, Fourth edition.

FAO and IIASA (2000) Diagnosis and improvement of saline and alkali sols, USDA Handbook No 60, U.S. Salinity Lab. Staff (1954), Washington

FAO (2016) Saline soils and their management. http:// www.fao.org/docrep/x5871e/x5871e04.htm.

FAO., (2005) Fertilizer use by crop in Egypt. Land and Plant Nutrition Management Service Land and Water Development Division,http://www.fao. org/3/a-y5863e.pdfhttp://www.fao.org/3/a-y5863e. pdf.

Garcia, G. (1978) Soil water Engineering Laboratory Manual. Colorado State Univ. Dept. of Agric. and Chemical Engineering. Fort collins, Colorado.

Herrick J. E. and Jones T. L. (2002). A dynamic cone penetrometer for measuring soil penetration resistance. Soil Sci. Soc. Am. J. 66, 1320-1324.

Jodi DeJong, H. (2004) Can subsoiling increase crop yields in Minnesota? Agric. World Wide Correspondent.MeredithCoporation.

Kolekar O. L., Patil,S. B. and Rathod, S.D. (2014) Effects of different mole spacings on the yield of summer groundnut.International Journal of
Research in Engineering and Technology. Volume: 03 Issue: 04. http://www.ijret.org.

Lickacz, J. (1993) Management of solonetzicsoils. Agdex 518-8.Revised, Edmonton, Alberta, Canada.

Masoud, F.I. (1969) Principles of Agricultural Irrigation. Dar Elmatboua tElgadidah, Alexandria (In Arabic).

Moukhtar, M. M., Aly, I.N. Abdel-Aal, ElSheikh,M.A.B. and Abdel-Khalik, M.I.I. (2002) The Role of Mole Drainage in Degradation Soils Under Saline Ground Water Table, Egypt. The Second International Conference on Sustainable Agriculture for Food, Energy and Industry September 8-13, Beijing, China.

Negm, A. M. (2017) The Nile Delta. HdbEnv. Chem. 55, 265-296.

Page, A.L., R.H. Miller and D.R. Keeney, (1982) Methods of Soil Analysis. Part П: Chemical and Microbiological Properties, $2^{\text {nd }}$ ed. Soil Sci. Soc. Am. Inc., Madison, USA.

Seleiman, M. F. and Kheir, A. M. S. (2018) Saline soil properties, quality and productivity of wheat grown with bagasse ash and thiourea in different climatic zones. Chemosphere, 193, 538-546.

Snedecor, G.W. and Cochran, W.G. (1980) "Statistical Methods" Iowa state Univ. Press., Ames., Iowa, USA. $7^{\text {th }}$ ed., 225-330.

Zalat, S.S., Abo Shady,Kh. A., Ibrahim.M.F.M. and Helal. Samia, M.M. (2011) Effect of injection ammonia gas under different levels and depths on yield and quality of sugar beet. J.Agric. Res. Kafr El-Sheikh Univ., 37 (1), 43-56.

(Received:17/4/2018; accepted:30/6/2018) 


\section{تأثير انفاق الصرف ومصادر التسميد النيتروجيني علي نشاط منطقه الجذور وانتاجيه الأرز في الأراضي الطينية المتأثره بالاملاح في شمال دلتئا النيل

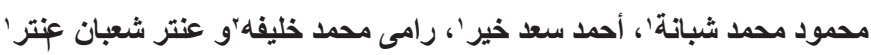

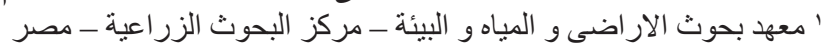

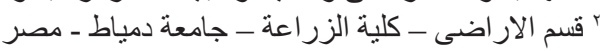

أن التكامل في عمل انفاق الصرف كنظام صرف ذوتكلفة اقتصادية منخفضة مع مصادر مختلفه من التسميد

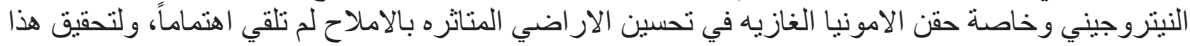

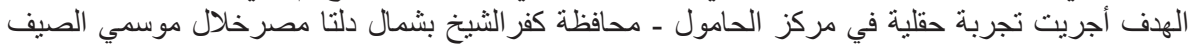

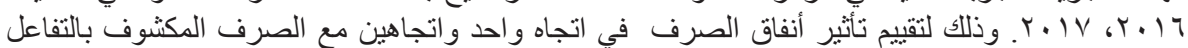

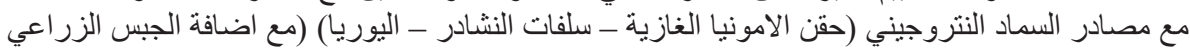

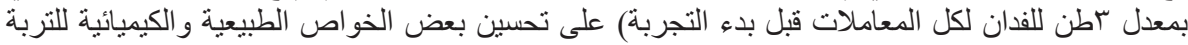

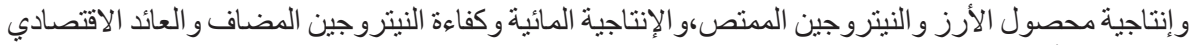

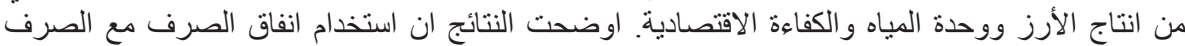

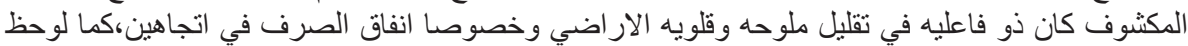

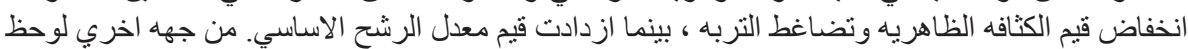

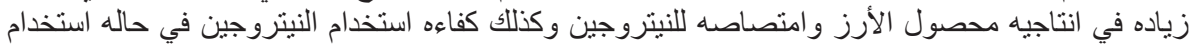

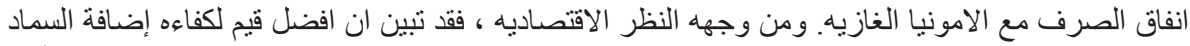

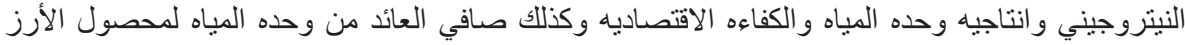

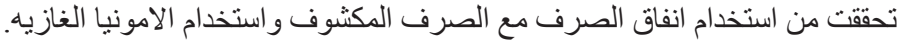

